\title{
Vitamin D Receptor Immunoexpression in Benign and Malignant Prostate Tumors
}

\author{
R. N. A. Ginting ${ }^{1}$, D. R. Anggraini ${ }^{2 *}$, M. S. Sitorus ${ }^{2}$ \\ ${ }^{1}$ Department of Histology, Faculty of Medicine, Universitas Sumatera Utara, Medan, Indonesia; ${ }^{2}$ Department of Anatomy, \\ Faculty of medicine, Universitas Sumatera Utara, Medan, Indonesia
}

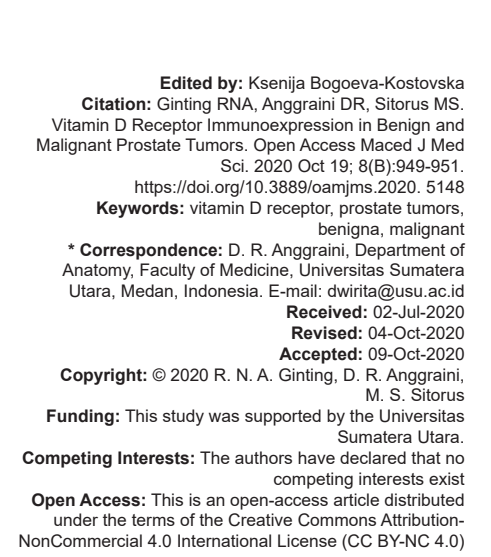

\section{Introduction}

Prostate cancer $(\mathrm{Pca})$ is the second common malignancy of men in the world and is the fifth leading cause of death, an estimated 307,000 deaths in 2012 [1]. In the United States, Pca mortality rates are increasing; in 2013, it was estimated 29,720 men died and in 2014, there will be an estimated 585,720 cancer deaths [2]. Physiologically, men who have age more than 50 years old usually occurred enlargement of the prostate, but not all prostate enlargement is Pca. Screening should be done by ultrasonography and prostatic specific antigen examination to determine whether the condition is benign prostatic hyperplasia (BPH) or Pca [3].

Recently, the role of calcitriol as a target therapy for cancer is often discussed. Target therapy is a specific therapy to inhibit factors that are considered as a cause of carsinogenesis process. Calcitriol is the most active of metabolite Vitamin D [4]. Calcitriol in vitro and in vivo experiments indicated synergistically with chemotherapy agents. Vitamin D is one of the hormones associated with a lower risk of several types of cancer, including Pca [5].

The prostate gland is an organ that has Vitamin D receptors (VDR) and responds to $1.25(\mathrm{OH}) 2 \mathrm{D}$. In addition, these tissues and cells express the enzyme 25-hydroxyvitamin D-1-hydroxylase which converts 25 $(\mathrm{OH}) \mathrm{D}$ to $1.25(\mathrm{OH}) 2 \mathrm{D}$. The active form of Vitamin $\mathrm{D}$ has been shown to have a strong cell regulation effect in cells besides also being involved in calcium homeostasis. These effects are mediated through VDR. The binding of VDR by $1.25(\mathrm{OH}) \mathrm{D}$ causes several cellular effects, including induced differentiation and apoptosis and inhibited proliferation, angiogenesis, and metastatic potential. Thus, Vitamin D is believed to play an important role in the etiology and treatment of cancer [6], [7].

VDR expression can be over-expression or under-expression (suppressed) in various types of cancer. Over-expression of VDR indicates a large number of VDRs so that it can bind calcitriol. The identification of VDR in tumor tissue by immunohistochemical examination is a good method and is a modality for the development of target therapy [8]. Therefore, this study was conducted to the detected expression of VDR in $\mathrm{BPH}$ and prostate adenocarcinoma.

\section{Methods}

The sample was a paraffin block from patients diagnosed with $\mathrm{BPH}$ and prostate adenocarcinomas at 
Grand Medistra Hospital, Lubuk Pakam, Medan. The inclusion criteria were cases diagnosed according to the WHO 2016 [9]. Exclusion criteria were damaged by paraffin blocks and samples that could not be daubed with hematoxylin-eosin and immunohistochemical VDR. Examination of immunohistochemical VDR is carried out at Anatomic Pathology Laboratory, Universitas Sumatera Utara.

This study consisted of two groups, namely, benign and malignant prostate, each with 30 samples. Thus, the malignant group divided three grades; low (grade 1 and 2), moderate (grade 3), and high (grade 4 and 5) according to the WHO criteria. This study was a descriptive-analytic with a cross-sectional approach. Permission and approval were obtained from the Medical Ethics Committee Faculty of Medicine, Universitas Sumatera Utara.

The VDR immunoexpression is immunoreactive tumor cells against appearance immunohistochemicals that use antibodies VDR. The assessment of VDR expression is done by the observed intensity and immunohistochemical outward distribution. Primary antibodies used are mouse anti-human VDR (D-6) antibody monoclonal (Medaysis) with a dilution of 1:500 in solution PBS. Intensity consists of negatives (score 0), weak (score 1), moderate (score 2), and strong (score 3). Distribution assessment is done with divide large field into four equal fields as a $25 \%$ distribution. Percentage of cells in all four fields then added and obtained into total VDR expression into one large field. The distribution level determined as $0=$ negative, $1 \leq 10 \%, 2=10-50 \%$ and $3=50 \%$. Based on the intensity value and distribution of VDR, expressions can be calculated histoscore (Intensity $\times$ Distribution), that is, weak (1-3), moderate (4-6), and strong (7-9) [10], [11].

\section{Results and Discussion}

The sample used is a paraffin block of the 60 patients included in this study (Table 1). The patient with age $>70$ years old more than age $<70$ years old. The mean age at diagnosis in this study was 69.2 years, and the youngest patient was 44 years. This is in line with studies done by Gurumurthy et al. and Jackson et al. [12], [13]. These findings confirm that Pca is a

Table 1: Characteristic clinicopathology of sample

\begin{tabular}{ll}
\hline Variable & $\mathrm{n}(\%)$ \\
\hline Age & 70 \\
Median & 69.2 \\
Range & $30(50)$ \\
Benign prostatic hyperplasia & $30(50)$ \\
Prostate adenocarcinoma & $9(30)$ \\
Low grade & $4(4.3)$ \\
Moderate grade & $17(56.7)$ \\
High grade & $60(100)$ \\
Total sample & \\
\hline
\end{tabular}

disease of elderly men, although young men are not excluded from the study.

Based on the results of immunoexpression, analysis showed positively strong VDR immunoexpression in $\mathrm{BPH}$ groups which were 12 cases $(40 \%)$, whereas the adenocarcinoma groups were 10 cases $(33.3 \%)$ (Table 2). Statistically, analysis showed not significant correlation $p=0.961$.

Table 2: Results of VDR immunoexpression in benign and malignant prostate tumors

\begin{tabular}{|c|c|c|c|c|c|c|c|}
\hline \multirow[t]{2}{*}{ Immunoexpression of VDR } & \multicolumn{2}{|c|}{$\mathrm{BPH}$} & \multicolumn{2}{|c|}{ Prostate adenocarcinoma } & \multicolumn{2}{|c|}{ Total } & \multirow[t]{2}{*}{$p$} \\
\hline & $\mathrm{N}$ & $(\%)$ & $\mathrm{N}$ & (\%) & $\mathrm{n}$ & (\%) & \\
\hline Weak & 5 & 16.7 & 5 & 16.7 & 10 & 16.7 & \\
\hline Moderate & 13 & 43.3 & 15 & 50 & 28 & 46.7 & 0.961 \\
\hline Strong & 12 & 40 & 10 & 33.3 & 22 & 36.6 & \\
\hline Total & 30 & 100 & 30 & 100 & 60 & 100 & \\
\hline
\end{tabular}

The results of immunoexpression VDR with the degree of differentiation of prostate adenocarcinoma are shown in Table 3. The data showed low-grade groups give results positively strong VDR immunoexpression of three cases $(10 \%)$, whereas high grade was 6 cases $(20 \%)$ with $p=0.906$. Totally, results showed that in all groups (low, moderate, and high), expression VDR in positively moderate was higher than positively strong. This study comparable with studies done by Hendrickson et al. showed that protein expression of VDR was highest with Gleason $3+3$ tumors and decreased with increasing pathologic Gleason score $(p<0.001)[5]$

Table 3: Results of VDR immunoexpression in prostate adenocarcinoma

\begin{tabular}{|c|c|c|c|c|c|c|c|c|c|}
\hline \multirow{3}{*}{$\begin{array}{l}\text { Immunoexpression } \\
\text { of VDR }\end{array}$} & \multicolumn{6}{|c|}{ Prostate adenocarcinoma } & \multirow{2}{*}{\multicolumn{2}{|c|}{ Total }} & \multirow[t]{3}{*}{$\mathrm{p}$} \\
\hline & \multicolumn{2}{|c|}{ Low grade } & \multicolumn{2}{|c|}{ Moderate grade } & \multicolumn{2}{|c|}{ High grade } & & & \\
\hline & $\mathrm{n}$ & $\%$ & $\mathrm{~N}$ & $\%$ & $\mathrm{n}$ & $\%$ & $\mathrm{n}$ & $\%$ & \\
\hline Weak & 1 & 3.3 & 0 & 0 & 4 & 13.3 & 5 & 16.7 & \\
\hline Moderate & 5 & 16.7 & 3 & 1 & 7 & 23.4 & 15 & 50 & 0.906 \\
\hline Strong & 3 & 10 & 1 & 3.3 & 6 & 20 & 10 & 33.3 & \\
\hline Total & 9 & 30 & 4 & 4.3 & 17 & 56.7 & 30 & 100 & \\
\hline
\end{tabular}

VDR tumor staining was evident intracellular in the cytoplasm, membrane cell, and nuclear [14]. There was considerable variability in staining of VDR across the $\mathrm{BPH}$ and prostate adenocarcinoma (Figure 1). The mechanism of VDR affected differentiation can be through genomic pathways in the nucleus that is Vitamin $D$ or, in its active form, calcitriol binds to VDR forming heterodimers with retinoic $X$ receptors (RXR) and with its ligands (nine cisretinoic acids). The dimer is forming complex with Vitamin $D$ responserelated elements with gene transcription to produce differentiation function [15], [16]. VDR also has nongenomic pathway that is in the cytoplasm with the mechanism of rapid action VDR binding to calcitriol on the VDR membrane in caveolae plasma membrane. Binding VDR with calcitriol on the plasma membrane activated several second messengers system.

The results of this study indicate that there is no correlation between VDR immunoexpression with benign and malignant prostate tumors. Expression VDR in positively moderate was higher than positively strong in benign and malignant prostate tumors, which may 


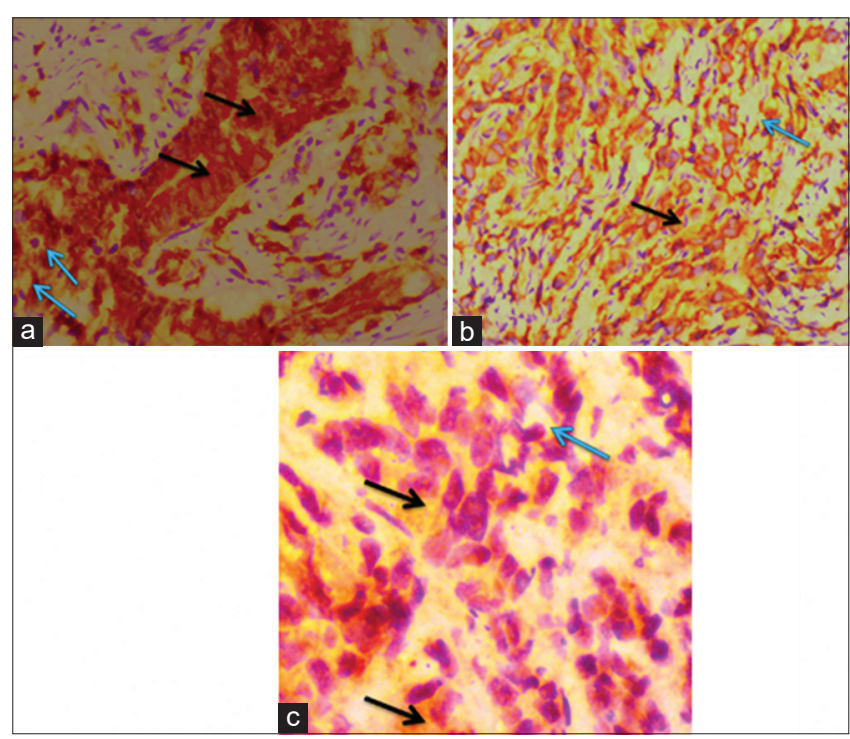

Figure 1: Overview of Vitamin D receptor immunoexpression. Strong intensity, cytoplasm (black arrow), and tumor cell membrane (blue arrow) dark brown shown in figure (a), while moderate-intensity, cytoplasm, and tumor cells are brown in color younger than the figure (a) is shown in figure (b). Weak intensity, cytoplasm, and tumor cell membrane light brown shown in figure (c). Image was taken 400x magnification

be another factor that influences; further, the study is needed. However, VDR correlates with the high-grade group may be the administration of Vitamin $D$ target therapy or in its active form; calcitriol can be given to the high-grade group.

\section{Conclusion}

Positive immunoexpression of VDR affected the differentiation of benign and malignant prostate tumors.

\section{References}

1. Ferlay J, Soerjomataram I, Ervik M, Dikshit R, Eser S, Mathers C, et al. Globocan 2012 Cancer Incidence and Mortality Worldwide: IARC Cancer Base No. 11. Lyon, France: International Agency for Research on Cancer; 2013. Available from: http://www. Iglobocan.iarc fr. [Last accessed on 2014 Nov 19].

2. American Cancer Society. Cancer Facts and Statistics 2014. Georgia, United States: American Cancer Society; 2014

3. Cabarkapa S, Perera M, McGrath S, Lawrentschuk N. Prostate cancer screening with prostate-specific antigen: A guide to the guidelines. Prostate Int. 2016;4(4):125-9. https://doi. org/10.1016/j.prnil.2016.09.002

\section{PMid:27995110}

4. Deeb KK, Trump DL, Johnson CS. Vitamin D signalling pathways in cancer: Potential for anticancer therapeutics. Nat Rev Cancer. 2007;7(9):684-700. https://doi.org/10.1038/nrc2196

\section{PMid: 17721433}

5. Hendrickson WK, Flavin R, Kasperzyk JL, Fiorentino M, Fang $\mathrm{F}$, Lis $\mathrm{R}$, et al. Vitamin $\mathrm{D}$ receptor protein expression in tumor tissue and prostate cancer progression. J Clin Oncol. 2011;29(17):2378-85. https://doi.org/10.1200/jco.2010.30.9880 PMid:21537045

6. Aminah H, Erida Y, Yulianti H, Hassan AH. Correlation of Vitamin $D$ receptor (VDR) expression with differentiation staging and grading in colorectal adenocarcinoma. MKB. 2016;48(2):123-8. https://doi.org/10.15395/mkb.v48n2.387.

7. Gupta D, Vashi PG, Trukova K, Lis CG, Lammersfeld CA. Prevalence of serum Vitamin $D$ deficiency and insufficiency in cancer: Review of the epidemiological literature. Exp Ther Med. 2011;2(2):181-93. https://doi.org/10.3892/etm.2011.205 PMid:22977487

8. Wang Y, Zhu J, DeLuca HF. Where is the Vitamin D receptor? Arch Biochem Biophys. 2012;523(1):123-33. https://doi. org/10.1016/j.abb.2012.04.001

PMid:22503810

9. Moch H, Humphrey PA, Ulbright TU, Reuter VE. WHO Classification of Tumours of the Urinary System and Male Genital Organs. Lyon: International Agency for Research on Cancer; 2016.

10. Kure S, Nosho K, Baba $\mathrm{Y}$, Irahara N, Shima K, Ng K et al. Vitamin D receptor expression is associated with PIK3CA and KRAS mutations in colorectal cancer. Cancer Epidemiol Biomarkers Prev. 2009;18(10):2765-72. https://doi. org/10.1158/1055-9965.epi-09-0490 PMid:19789368

11. Erida $\mathrm{Y}$, Aminah $\mathrm{H}$, Yulianti $\mathrm{H}$, Hernowo BS Vitamin D Receptor (VDR) and phosphatidylinositol 3-kinase (PI3K) independently affected colorectal adenocarcinoma differentiation. Indones $\mathrm{J}$ Clin Pharm. 2015;4(4):264-74

12. Gurumurthy D, Maggad R, Patel S. Prostate carcinoma: Correlation of histopathology with serum prostate specific antigen. Sci J Clin Med. 2015;4(4-1):1-5. https://doi. org/10.11648/j.sjcm.s.2015040401.11

13. Jackson LA, McGrowder DA, Lindo RA. Prostate specific antigen and gleason score in men with prostate cancer at a private diagnostic radiology centre in Western Jamaica. Asian Pac J Cancer Prev. 2012;13(4):1453-6. https://doi.org/10.7314/ apjcp.2012.13.4.1453 PMid:22799347

14. Pike JW, Meyer MB. The Vitamin D receptor: New paradigms for the regulation of gene expression by 1,25-dihydroxyvitamin D(3). Endocrinol Metab Clin North Am. 2010;39(2):255-69. https://doi.org/10.1016/j.ecl.2010.02.007

PMid:20511050

15. Gocek E, Studzinski GP. Vitamin D and differentiation in cancer. Crit Rev Clin Lab Sci. 2009;46(4):190. https://doi. org/10.1080/10408360902982128

\section{PMid:19650715}

16. Pereira F, Larriba MJ, Munoz A. Vitamin D and colon cancer. Endocr Relat Cancer. 2012;19(3):R51-71. https://doi. org/10.1530/erc-11-0388

PMid:22383428 